\title{
Weighting Key Factors for Port Congestion by AHP Method
}

\section{Pelin BOLAT ${ }^{1}$, Gizem KAYIŞOĞLU² ${ }^{2}$, Emine GÜNEŞ ${ }^{3}$, Furkan Eyüp KIZILAY ${ }^{4}$, Soysal ÖZSÖĞÜT ${ }^{5}$}

1, 2,5 Istanbul Technical University, Maritime Faculty, Turkey

${ }^{3}$ Bandirma Onyedi Eylul University, Maritime Faculty, Turkey

${ }^{4}$ Piri Reis Vocational and Technical Anatolian High School, Maritime Area, Turkey

byilmazp@itu.edu.tr; ORCID ID: https://orcid.org/0000-0003-4262-3612

yukselg@itu.edu.tr; ORCID ID: https://orcid.org/0000-0003-2730-9780

egunes@badirma.edu.tr; ORCID ID: https://orcid.org/0000-0003-3835-9089

ef.eyup.kizilay@gmail.com; ORCID ID: https://orcid.org/0000-0002-0576-534X

soysalozsogut@yahoo.com.tr; ORCID ID: https://orcid.org/0000-0002-2553-125X

Corresponding Author: Emine GÜNEŞ

\begin{abstract}
Port congestion is one of the most important factors for measuring port performance and a critical problem that affects seaports' performance, productivity and efficiency levels as well. Determining the most important factors affecting the port congestion in detail contributes to the economic and social growth of the ports. This paper makes an effort to contribute to the existing literature by determining importance weights of factors leading to port congestion as the unique study on the matter. Therefore, it is aimed to identify the most important factors on port congestion according to the port state control, flag state control and independent surveyors' points of views. For this purpose, a literature research was conducted on the factors causing port congestion and experts on the field were consulted. Then the collected data were classified in a list and the determined factors have been ordered with Analytic Hierarchy Process method by experts. The importance weights of the factors have been identified and the most significant factors for port congestion have been obtained with the pairwise comparison of the criteria. According to the results, it can be argued that the most important main factors for port congestion are documentation procedures, port operation and management, ship traffic inputs, port structure and strategy and government relations, respectively.
\end{abstract}

\section{Keywords}

Port Congestion, AHP, Criteria for Port Congestion

To cite this article: Bolat, P., Kayişoğlu, G., Güneş, E., Kızılay, F. E., \& Özsöğüt, S. (2020). Weighting Key Factors for Port Congestion by AHP Method. Journal of ETA Maritime Science, 8(4), 252-273.

To link to this article: https://dx.doi.org/10.5505/jems.2020.64426 


\section{Introduction}

Commercial shipping is a key factor in international goods transportation, therefore international trade depends on shipping by means of moving cargo from one region to another. For international trade, new shipping demands to accommodate different types of cargoes and new ship designs for a faster long distance freight transport, ensuring a minimum cost per long tonnage. [1]. It is also compatible with the development of seaports for increased rate of international trade and transportation, for efficient loading and unloading of cargo from ships. At this point, ports must be operated efficiently, with enough space to accommodate berths, with modern technological transport equipment and ships, sufficient skilled manpower, efficient handling of documentation process and, storage facilities and good infrastructure [2]. For instance, Tongozo[3] states that the efficiency of a port is crucial for achieving competitive advantages and it is expressed through the provision of good services that are expected by ship owners and customers. According to Nilsson[4], one of the most important factors to consider for measuring port performance is also port congestion.

From this point of view, it can be said that port congestion is a critical problem, which affects seaports' performance, productivity and efficiency levels. It is a fact that ships create congestion at the port entrances by using a lot of time in the channel or during berthing. The ships wait in the anchorage area and line up for berthing to the port. The waiting time is calculated using the service time of the ships. Ships' service time is a way to measure the efficiency of ports. The congestion is a fact that because of the cargoes reach up to quantities that are much more than the port's handling and storage capacity as well as capacity of the allocated space they can be moved.

Various factors that may cause port congestion have been specified by most studies. These are listed in general headings as follows [5]: inefficient and old port infrastructure, inconsistent governments' policies, failure to meet technological trends in globalization and manpower problems of some ports, excessive demand for supply of port services. When the factors that cause port congestion are examined in detail, the following items are encountered[6]:reserving the port or terminal beyond its capacity, industrial actions or strikes, pandemics such as COVID-19, lack of allocated space or stockpile, delays due to bad weather resulting in ships lining up outside, war, limited port access, lack of port handling equipment, slow productivity, hinterland connections and location of the port. Port congestion, caused by a variety of factors may also add some extra costs to the supply chain, such as inventory costs and exorbitant demurrage costs. Jansson and Shneerson[7] stated that the effect of port congestion on economic as follows: 'Congestion costs exist if the other short-run costs of port operations, per unit of throughput, are an increasing function of the actual capacity utilization. When actual demand exceeds capacity, extreme congestion costs arise, which we call queuing costs. When a port is said to be congested, it is commonly meant that ships are queuing, waiting to obtain a berth'.

Considering the effects of the port congestion problem on a port as mentioned above, in order to any port not to encounter with this problem, modern ports must focus on investing in modern equipment and other infrastructures to develop and expand the port area for compensating increased cargo volume of ships. On the other hand, by determining the most important factors via considering the factors affecting the congestion of the port in detail, contributes to the economic and social growth of the ports. 
In this context, it is aimed to identify most important factors on congestion of a port, according to the port state control, flag state control, and independent surveyors' points of views. For this purpose, first factors causing port congestion were researched from the literature, experts were consulted and the collected data were classified in a list. Then, the determined factors have been ordered by experts, in accordance with Analytic Hierarchy Process (AHP) method. As part of the scope of this study, experts have been designated as independent, port state and flag state surveyors who have been empowered to carry out various inspections in accordance with national and international conventions and rules for ships approaching ports. By the pairwise comparison of criteria, the importance weights of the factors have been identified via the AHP method and the most significant factors for port congestion have been obtained.

For this purpose, factors causing port congestion were researched from the literature, experts were consulted and the collected data were classified in a list. Therefore, the ports that have port congestion problems gain an insight into which area they should improve and a port investor can also refer to these factors when creating a port project.

\section{Literature Review}

Congestion of ports, as one of the major reason of disruptions to maritime transport operation networks, results infertility and increase the costs of logistics and trade[2] [8].

Although port congestion is defined as "waiting for berthing" in literature, additional concerns are possible when mentioned port congestion by separating as "major categories of congestion". These are; ship berth congestion, ship work congestion, vehicle gate congestion, vehicle work congestion, ship entry/exit route congestion, and additionally cargo stack congestion[5][9].

Considering port selection, both port congestion and distance of navigation are major determinants for shippers[10]. On the other hand, Nilsson [4] states that not only distance of navigation and port congestion but also distance of the shipper from port, distance from origin and to destination and shipping line's fleet size affects shippers' port choice. In another study, Lirn et al [11] examines the transshipment port selection by global carries by AHP method to explore factors affect port selection criteria and advices in strategic perspective to transshipment market.

In the sense of the container ports, continuous growth in container transportation by vessels which puts industry under pressure results with congestions at port land entries and that situation affects port productivity negatively [6][12]. Port productivity in container terminals has direct influence on port efficiency and not only depends on psychical factors but also organizational factors [13].

On the other hand, considering the issue of port congestion, the unique nature of the port, which differs from port to port, should be taken into account [9]. Several studies have been made regarding port congestion both for optimization to increase port efficiency and analysis of policies about increase of psychical structures, capacity and modernization. Oyatoye et al [14] highlight the importance of queuing theory to the port congestion problem to increase the sustainable development of Nigerian ports. The study determines that the number of berths in the port of Nigeria was sufficient for the traffic density of the ships, includes the content analysis of the interview with the stakeholders at the port and other factors that caused port congestion. Also, policy recommendations are made for a cost-effective and more 
attractive solution that also includes the rapid return of ships in Nigerian port. Maneno [2] evaluates factors affecting port congestion for Port of Dar es Salaam / Tanzania. For that purpose, Maneno makes a literature review and list the factors of port congestion, prepares a questionnaire and makes a survey with stakeholders. In the result, Maneno makes recommendations both psychical and organizational for solution of port congestion problem in Port of Dar es Salaam. In another study, land side congestion of traffic for The Consorzio Napoletano Terminal Containers (CO. NA.TE.CO.), located in the Port of Naples / Italy analyzed with Queuing theory and according to results offer solutions [15]. As an alternative truck chassis exchange terminal to increase truck flow in container terminals [16]. Another optimization study by Jin et al [17] puts another solution alternative to berth congestion problem by column generation based approach to optimize container flow by berth and yard design.

Even if several studies made regarding mitigate port congestion and it's factors by optimization or mathematical methods, the best way for removing port congestion is using modern equipment, expanding terminal size and capacities, which is inevitable for some countries to keep their role upright in maritime transportation, such as Canada [2][18][19]. Besides, for several countries, port congestion is a major problem and needs to be organized both by governments and private sector for best results. Cullinane and Song [20] evaluate The Republic of Korea and showing as an example to developing countries in strategic planning. Potgieter [21] focuses on Cape Town Container Terminal and uses both qualitative and quantitative methods for identification, analyze evaluation and recommendations for mitigation of port congestion factors. Fan et al [22] investigates congestion problem in container terminals of USA with spatial competition and explores the negative results of the consequences. Emecen[23] compares supply and demand in Marmara ports by queuing theory. The study results the current capacity is enough to handle ship flow and gives recommendations in case of increase on demand. Zorlu [24] examines port clutter in Turkey, highlights the importance and magnitude of The Gulf of İzmit area ports and recommends building a big transit port to the area. Yeo et al [25] analyze the effects of vessel traffic conditions in 2011 for Busan and assess the potential for marine traffic congestion using the AWE-SIM simulation program. According to the results, enlarging of the superstructure of the container terminals, the reallocation of terminal functions in number two pier, and the elimination of anchorage are the emergent tasks to minimize possible congestion for Busan. Abu Alhaol et al [26] present three maritime port congestion indicators mined using static and dynamic messages of Automatic Identification System. The considered indicators are time of service criticality, spatial density, and, spatial complexity. They proposed that these indicators can be used by port authorities and other maritime stakeholders to predict for future congestion levels that can be correlated to high demand, weather, or a sudden collapse in capacity due to sabotage, strike, or other disruptive events. Saeed et al [27] explain governance strategies that several players in the maritime field can adopt to decrease port congestion by developing a conceptual model. For examining port congestion decrease from a governance perspective, they use frequency, and uncertainty, asset specificity, and prevail in the maritime sector as three characteristics of transaction cost analysis. According to their study, the main reasons for port congestion are caused by other members of the port supply chain. These factors can be 
frequency of cargo (mega vessels), and/or environmental uncertainty (for example, trucker strikes, bad weather). Neagoe et al [28] present a paper that highlights "how a supply chain perspective deploying information systems can improve port congestion management by stimulating collaboration amongst multiple transport and terminal operators". They state that one of the reasons of congestion management systems' low solution acceptance because of the trucking industry. This is caused by lack of engagement from the port or terminal operators, inflexible systems to transporters' business demands, and onesided benefits derived by the terminal from the congestion management systems. Li et al [29] present "a hybrid simulation model that combines traffic-flow modeling and discrete-event simulation for landside port planning and evaluation of traffic conditions for a number of whatif scenarios". They show that problem of port congestion is resulted from external vehicles traveling in spaces with very limited traffic regulation and complexity of heterogeneous closed-looped internal vehicles and the traffic interactions with port operations such as loading and unloading cargoes. Pruyn et al [30] introduce a study to predict port waiting times for Mormugoa, New Mangalore, Shanghai, and Esperance ports because of congestion by using historical data from 2012 to 2015 in the Markov chain analysis. They state that forecasting the waiting time in a port can enhance the planning and efficiency of the transportation of cargoes.

For summarizing the literature review regarding port congestion, Table 1 is introduced.

The distinctive feature of this paper from the other studies in the literature is the effort to gather all the studies on the port congestion and its factors in detail, specifically to prove which factors are most important on port congestion. In the literature there aren't many studies available that the most important factors on port congestion present via scientific analysis clearly.

\section{Methodology}

\subsection{Analytic Hierarchy Process (AHP)}

Analytic Hierarchy Process (AHP) represents the hierarchical structure of a system and is developed at first for military by Thomas Saaty in 1980 [31]. The hierarchy, which is formed by various levels including decomposition of main goal to a set of class and sub class, and final level, summarizes the factors according to the goal of the system as in Figure 1. The class of the hierarchical structure is named as criteria or attribute and the sub class of the structure is called as sub criteria or sub attribute. If a multi criteria decision making (MCDM) is the point in question, the alternatives take part in the final level of the hierarchical structure. AHP is the popular method as the methodological procedure since it can be easily performed with multiple, objective programming formulations via the interactive solution process. The basis of the method is based on pairwise comparison of criteria and alternatives by the experts [32].

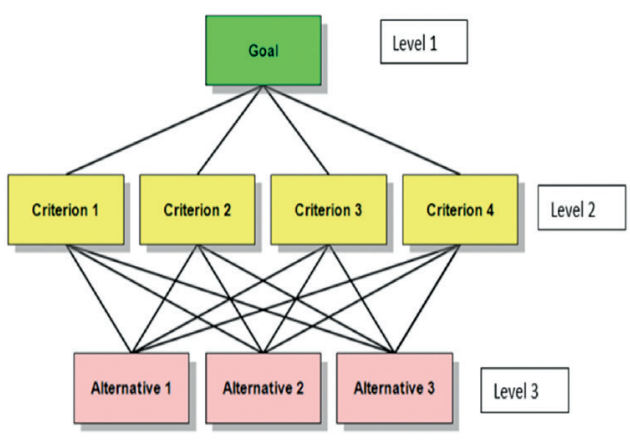

Figure 1. Sample Hierarchical Structure for AHP 
Table 1. Summary of Literature Review

\begin{tabular}{|c|c|c|c|c|}
\hline Author & $\begin{array}{l}\text { Title of } \\
\text { Study }\end{array}$ & Methodology & The Aim of The Study & Findings or Suggestion \\
\hline $\begin{array}{l}\text { Fadhili } \\
\text { HarubuManeno } \\
\text { (2019) }\end{array}$ & $\begin{array}{l}\text { Assessment } \\
\text { of factors } \\
\text { causing port } \\
\text { congestion: } \\
\text { a case of the } \\
\text { port Dar es } \\
\text { Salaam }\end{array}$ & $\begin{array}{l}\text { Questionnaires and } \\
\text { quantitative methods } \\
\text { in data collections } \\
\text { Praxeology design }\end{array}$ & $\begin{array}{l}\text { The main purpose of } \\
\text { the study is to reveal the } \\
\text { factors causing congestion } \\
\text { in Dar es Salaamharbor } \\
\text { through a survey for } \\
\text { investigatingthe challenges } \\
\text { faced by port stakeholders } \\
\text { and providing solutions to } \\
\text { this problem. }\end{array}$ & $\begin{array}{l}\text { The findings of this study } \\
\text { showed that Dar es Salaam is } \\
\text { faced with various challenges } \\
\text { such as documentation } \\
\text { procedures, unskilled } \\
\text { manpower, poor policy, use of } \\
\text { information, communication } \\
\text { and information systems, } \\
\text { inadequate equipment, } \\
\text { bureaucracy, port } \\
\text { infrastructure, poor } \\
\text { management planning. }\end{array}$ \\
\hline $\begin{array}{l}\text { Ibeawuchi } \\
\text { C. } \\
\text { Nze\&Chined } \\
\text { umOnyemec } \\
\text { hi (2018) }\end{array}$ & $\begin{array}{l}\text { Port congestion } \\
\text { determinants } \\
\text { and impacts on } \\
\text { logistics and } \\
\text { supply chain } \\
\text { network of five } \\
\text { African ports }\end{array}$ & $\begin{array}{l}\text { This analytical tool } \\
\text { differs slightly from the } \\
\text { commonly used queuing } \\
\text { theory model, which } \\
\text { mostly aims to take into } \\
\text { account the arrival and } \\
\text { service time of ships and } \\
\text { cargoes at ports. }\end{array}$ & $\begin{array}{l}\text { The main purpose of this study } \\
\text { is determine the effects of port } \\
\text { congestion on Logistics and } \\
\text { Supply chain according to some } \\
\text { Sub-Saharan African ports. }\end{array}$ & $\begin{array}{l}\text { The findings of the regression } \\
\text { analysis reveal that congestion } \\
\text { in African ports is entirely due } \\
\text { to planning, regulation, capacity, } \\
\text { efficiency, or a combination of } \\
\text { these. }\end{array}$ \\
\hline $\begin{array}{l}\text { Usman Gidado } \\
(2015)\end{array}$ & $\begin{array}{l}\text { Consequences } \\
\text { of Port } \\
\text { Congestion on } \\
\text { Logistics and } \\
\text { Supply Chain } \\
\text { in African } \\
\text { Ports }\end{array}$ & $\begin{array}{l}\text { This article examines } \\
\text { common port } \\
\text { congestion scenarios, } \\
\text { their extent, and the } \\
\text { various factors that } \\
\text { trigger congestion } \\
\text { in Lagos, Durban, } \\
\text { Mombasa ports. }\end{array}$ & $\begin{array}{l}\text { This article examines the } \\
\text { common port congestion } \\
\text { scenarios, sizes, and } \\
\text { various factors that trigger } \\
\text { congestion in the ports of } \\
\text { Lagos, Durban, Mombasa } \\
\text { and the collection ports of } \\
\text { the Suez Canal. }\end{array}$ & $\begin{array}{l}\text { The Durban and Port Said } \\
\text { facilities have proved to be } \\
\text { the most congestion-resistant } \\
\text { ports in Africa, largely due } \\
\text { to the robust strategies } \\
\text { adopted in the operational } \\
\text { distribution of ports and cargo } \\
\text { management. }\end{array}$ \\
\hline $\begin{array}{l}\text { Firat Bolat\& Nil } \\
\text { Güler (2015) }\end{array}$ & $\begin{array}{l}\text { Hub port } \\
\text { potential of } \\
\text { Marmara } \\
\text { region in } \\
\text { Turkey by } \\
\text { network- } \\
\text { based } \\
\text { modelling }\end{array}$ & $\begin{array}{l}\text { In this study, } \\
\text { network-based hub } \\
\text { port assessment } \\
\text { (NHPA) model is } \\
\text { used. }\end{array}$ & $\begin{array}{l}\text { The main purpose of } \\
\text { this study is to evaluate } \\
\text { whether the port regions } \\
\text { of Ambarl,, Gemlik, } \\
\text { İstanbul, İzmit and } \\
\text { Tekirdağ have the potential } \\
\text { to become a main port } \\
\text { using the NHPA model. }\end{array}$ & $\begin{array}{l}\text { As a result of the increase in } \\
\text { container handling, increases } \\
\text { in activity and economies of } \\
\text { scale were reflected in the } \\
\text { connectivity index. As a result } \\
\text { of the instant and active use } \\
\text { of this port, the connectivity } \\
\text { index has increased and } \\
\text { the collaborative index has } \\
\text { decreased. }\end{array}$ \\
\hline $\begin{array}{l}\text { TC Lirn, HA } \\
\text { Thanopoulou, MJ } \\
\text { Beynon \& AKC } \\
\text { Beresford (2004) }\end{array}$ & $\begin{array}{l}\text { An Application } \\
\text { of AHP on } \\
\text { Transhipment } \\
\text { Port Selection: } \\
\text { A Global } \\
\text { Perspective }\end{array}$ & $\begin{array}{l}\text { Approach An Analytic } \\
\text { Hierarchy Process } \\
\text { (AHP) }\end{array}$ & $\begin{array}{l}\text { This study examines } \\
\text { the dominant factors } \\
\text { influencing shippers' } \\
\text { port selection decisions } \\
\text { using Analytical Hierarchy } \\
\text { Process (AHP). }\end{array}$ & $\begin{array}{l}\text { The results of the AHP } \\
\text { analysis revealed that both } \\
\text { global container carriers and } \\
\text { port service providers have } \\
\text { similar perception of the } \\
\text { service features are the most } \\
\text { important for transfer port } \\
\text { selection. }\end{array}$ \\
\hline $\begin{array}{l}\text { HarieshManaadiar } \\
(2020)\end{array}$ & $\begin{array}{l}\text { Port } \\
\text { Congestion } \\
\text { - causes, } \\
\text { consequences } \\
\text { and impact on } \\
\text { global trade }\end{array}$ & - & $\begin{array}{l}\text { In this study, it is aimed } \\
\text { to examine the Port } \\
\text { Congestion - its causes, } \\
\text { consequences and its } \\
\text { impact on global trade. }\end{array}$ & $\begin{array}{l}\text { Globalization has led to } \\
\text { containerization, leading to an } \\
\text { increase in global container } \\
\text { trade, which has grown by } \\
\text { an average of } 9.5 \% \text { since the } \\
1980 \text { s. Between } 2000-2018 \text {, } \\
\text { the global container port } \\
\text { business volume increased } \\
\text { by } 254 \% \text {. }\end{array}$ \\
\hline
\end{tabular}


Table 1. Summary of Literature Review (Cont')

\begin{tabular}{|c|c|c|c|c|}
\hline Author & $\begin{array}{l}\text { Title of } \\
\text { Study }\end{array}$ & Methodology & The Aim of The Study & Findings or Suggestion \\
\hline $\begin{array}{l}\text { Chang Qian Guan } \\
\text { (2009) }\end{array}$ & $\begin{array}{l}\text { Analysis } \\
\text { of marine } \\
\text { container } \\
\text { terminal gate } \\
\text { congestion, } \\
\text { truck waiting } \\
\text { cost, and } \\
\text { system } \\
\text { optimization }\end{array}$ & $\begin{array}{l}\text { 1) data analysis } \\
\text { 2) field observations, } \\
\text { 3) development of the } \\
\text { queuing model, } \\
\text { 4) model validation } \\
\text { and verification, } \\
\text { 5) synthetic analysis, } \\
\text { 6) sensitivity analysis, } \\
\text { and } \\
\text { 7) gate congestion } \\
\text { mitigation } \\
\text { alternatives. }\end{array}$ & $\begin{array}{l}\text { The aim of this thesis is } \\
\text { to analyze the MCT door } \\
\text { system study to measure } \\
\text { the economic costs of } \\
\text { the gate congestion } \\
\text { and develop a model } \\
\text { to measure, provide } \\
\text { alternatives to optimize } \\
\text { door operation and reduce } \\
\text { the gate congestion } \\
\text { in New York Harbor } \\
\text { is to investigate the } \\
\text { alternatives. }\end{array}$ & $\begin{array}{l}\text { This study provides a } \\
\text { comprehensive analysis of this } \\
\text { issue, including measuring the } \\
\text { cost of congestion and offers } \\
\text { several alternatives to reduce } \\
\text { congestion. }\end{array}$ \\
\hline $\begin{array}{l}\text { E.OOyatoye } \\
\text { S.O.Adebiyi, } \\
\text { J.COkoyeeB.B } \\
\text { Amole, }(2011)\end{array}$ & $\begin{array}{l}\text { Application } \\
\text { of queueing } \\
\text { theory to port } \\
\text { congestion } \\
\text { problem in } \\
\text { Nigeria }\end{array}$ & $\begin{array}{l}\text { The queue model has } \\
\text { been applied to the } \\
\text { arrival and service } \\
\text { model that causes } \\
\text { congestion problems } \\
\text { and provides } \\
\text { solutions to problem } \\
\text { areas. }\end{array}$ & $\begin{array}{l}\text { This article aims to } \\
\text { examine the problem } \\
\text { of port congestion with } \\
\text { queuing theory in order to } \\
\text { increase the sustainable } \\
\text { development of Nigerian } \\
\text { ports. }\end{array}$ & $\begin{array}{l}\text { It is recommended that } \\
\text { concessionaires at the } \\
\text { ports be authorized to start } \\
\text { extensive infrastructure } \\
\text { development and capacity } \\
\text { building. }\end{array}$ \\
\hline $\begin{array}{l}\text { I. M. Veloqui, M. M. } \\
\text { Turias, M. J. Cerbán, } \\
\text { G. GonzálezBuiza, } \\
\text { and J. Beltrán } \\
\text { (2014) }\end{array}$ & $\begin{array}{l}\text { Simulating } \\
\text { the Landside } \\
\text { Congestion in } \\
\text { a Container } \\
\text { Terminal. The } \\
\text { Experience } \\
\text { of the Port of } \\
\text { Naples (Italy) }\end{array}$ & $\begin{array}{l}\text { A queuing model } \\
\text { has been developed } \\
\text { to analyze the } \\
\text { congestion problem. }\end{array}$ & $\begin{array}{l}\text { This study aims to examine } \\
\text { the reasons why Consorzio } \\
\text { Napoletano Terminal } \\
\text { Containers (CO.NA.TE.CO.) } \\
\text { in the Port of Naples are } \\
\text { constantly subject to traffic } \\
\text { congestion. }\end{array}$ & $\begin{array}{l}\text { The study shows that the } \\
\text { solution must take into } \\
\text { account the reduction in } \\
\text { service time at the access } \\
\text { gate and in the field } \\
\text { simultaneously. }\end{array}$ \\
\hline $\begin{array}{l}\text { Samuel Monday } \\
\text { Nyema (2014) }\end{array}$ & $\begin{array}{l}\text { Factors } \\
\text { influencing } \\
\text { container } \\
\text { terminals } \\
\text { efficiency: a } \\
\text { case study } \\
\text { of mombasa } \\
\text { entry port }\end{array}$ & $\begin{array}{l}\text { Data Envelopment } \\
\text { Analysis (DEA) } \\
\text { application has been } \\
\text { used in the port } \\
\text { industry to measure } \\
\text { port efficiency and } \\
\text { performance. }\end{array}$ & $\begin{array}{l}\text { The main purpose of } \\
\text { the study is to evaluate } \\
\text { the factors affecting the } \\
\text { efficiency of container } \\
\text { terminals in the Maritime } \\
\text { industry with the case } \\
\text { study of Mombasa Port of } \\
\text { Entry in the Republic of } \\
\text { Kenya. }\end{array}$ & $\begin{array}{l}\text { More research should be } \\
\text { done in the following areas: } \\
\text { Maritime Freight Transport } \\
\text { Logistics Container Terminals } \\
\text { Container Security Policy } \\
\text { Implementation and Role of } \\
\text { Global Supply Chain Security. }\end{array}$ \\
\hline $\begin{array}{l}\text { R. Dekker, S. Van } \\
\text { Der Heide, E. Van } \\
\text { Asperen, and P. } \\
\text { Ypsilantis (2013) }\end{array}$ & $\begin{array}{l}\text { A chassis } \\
\text { exchange } \\
\text { terminal to } \\
\text { reduce truck } \\
\text { congestion } \\
\text { at container } \\
\text { terminals }\end{array}$ & $\begin{array}{l}\text { The typical operation } \\
\text { of a container } \\
\text { terminal and the } \\
\text { CET @ solution are } \\
\text { outlined, and their } \\
\text { effects are measured } \\
\text { in terms of both cost, } \\
\text { environmental and } \\
\text { efficiency. }\end{array}$ & $\begin{array}{l}\text { In this article, a chassis } \\
\text { exchanges terminal } \\
\text { concept to reduce } \\
\text { congestion is presented } \\
\text { and analyzed. }\end{array}$ & $\begin{array}{l}\text { Because there is no real } \\
\text { handling bottleneck, it also } \\
\text { removes the uncertainty of } \\
\text { retrieving containers, allowing } \\
\text { trucking companies to } \\
\text { schedule multiple trips from } \\
\text { customers to CET each day. }\end{array}$ \\
\hline $\begin{array}{l}\text { R. Dekker, S. Van } \\
\text { Der Heide, E. Van } \\
\text { Asperen, and P. } \\
\text { Ypsilantis (2013) }\end{array}$ & $\begin{array}{l}\text { A chassis } \\
\text { exchange } \\
\text { terminal to } \\
\text { reduce truck } \\
\text { congestion } \\
\text { at container } \\
\text { terminals }\end{array}$ & $\begin{array}{l}\text { The typical operation } \\
\text { of a container } \\
\text { terminal and the } \\
\text { CET @ solution are } \\
\text { outlined, and their } \\
\text { effects are measured } \\
\text { in terms of both cost, } \\
\text { environmental and } \\
\text { efficiency. }\end{array}$ & $\begin{array}{l}\text { In this article, a chassis } \\
\text { exchanges terminal } \\
\text { concept to reduce } \\
\text { congestion is presented } \\
\text { and analyzed. }\end{array}$ & $\begin{array}{l}\text { Because there is no real } \\
\text { handling bottleneck, it also } \\
\text { removes the uncertainty of } \\
\text { retrieving containers, allowing } \\
\text { trucking companies to } \\
\text { schedule multiple trips from } \\
\text { customers to CET each day. }\end{array}$ \\
\hline
\end{tabular}


Table 1. Summary of Literature Review (Cont')

\begin{tabular}{|c|c|c|c|c|}
\hline Author & $\begin{array}{l}\text { Title of } \\
\text { Study }\end{array}$ & Methodology & The Aim of The Study & Findings or Suggestion \\
\hline $\begin{array}{l}\text { J. G. Jin, D. H. Lee, } \\
\text { and H. Hu (2015) }\end{array}$ & $\begin{array}{l}\text { Tactical berth } \\
\text { and yard } \\
\text { template } \\
\text { design at } \\
\text { container } \\
\text { transshipment } \\
\text { terminals: } \\
\text { A column } \\
\text { generation- } \\
\text { based } \\
\text { approach }\end{array}$ & $\begin{array}{l}\text { A set spanning } \\
\text { formulation has } \\
\text { been developed for } \\
\text { the berth and yard } \\
\text { template design } \\
\text { problem. Column- } \\
\text { based heuristics } \\
\text { are developed and } \\
\text { evaluated with } \\
\text { computational } \\
\text { experiments. }\end{array}$ & $\begin{array}{l}\text { This article addresses } \\
\text { the problem of berthing } \\
\text { congestion by presenting } \\
\text { a proactive management } \\
\text { strategy from a terminal } \\
\text { perspective that adjusts } \\
\text { ships' calling schedule } \\
\text { so that it can balance the } \\
\text { distribution of workload } \\
\text { on the dock side. }\end{array}$ & $\begin{array}{l}\text { Computational experiments } \\
\text { on real-world test samples } \\
\text { have demonstrated the } \\
\text { efficiency and effectiveness of } \\
\text { the proposed approach. }\end{array}$ \\
\hline $\begin{array}{l}\text { G. Y. Ke, K. W. Li, } \\
\text { and K. W. Hipel } \\
(2012)\end{array}$ & $\begin{array}{l}\text { An integrated } \\
\text { multiple } \\
\text { criteria } \\
\text { preference } \\
\text { ranking } \\
\text { approach } \\
\text { to the } \\
\text { Canadian west } \\
\text { coast port } \\
\text { congestion } \\
\text { conflict }\end{array}$ & $\begin{array}{l}\text { In the study, a } \\
\text { holistic conflict } \\
\text { analysis approach } \\
\text { that includes the } \\
\text { Analytical Hierarchy } \\
\text { Process (AHP) based } \\
\text { preference ranking } \\
\text { method in the } \\
\text { Conflict Resolution } \\
\text { Graph Model (GMCR) } \\
\text { was used. }\end{array}$ & $\begin{array}{l}\text { This article explores the } \\
\text { port congestion dispute on } \\
\text { Canada's west coast. }\end{array}$ & $\begin{array}{l}\text { The strategic analysis carried } \\
\text { out in this research suggests } \\
\text { possible decisions that Canada } \\
\text { will expand its port facilities } \\
\text { in various locations and } \\
\text { encourage traders to continue } \\
\text { choosing Canada's west coast } \\
\text { as one of the trading gateways } \\
\text { to North America. }\end{array}$ \\
\hline $\begin{array}{l}\text { M. Mollaoğlu, U. } \\
\text { Bucak, and H. } \\
\text { Demirel (2019) }\end{array}$ & $\begin{array}{l}\text { A Quantitative } \\
\text { Analysis of the } \\
\text { Factors That } \\
\text { May Cause } \\
\text { Occupational } \\
\text { Accidents at } \\
\text { Ports }\end{array}$ & $\begin{array}{l}\text { The Fuzzy Analytical } \\
\text { Hierarchy Process } \\
\text { (FAHP) method }\end{array}$ & $\begin{array}{l}\text { The purpose of this study } \\
\text { is to determine the risks } \\
\text { that cause Occupational } \\
\text { Health and Safety (OHS) } \\
\text { violations in the port } \\
\text { area and to reveal the } \\
\text { prominent risks as a result } \\
\text { of expert examinations. }\end{array}$ & $\begin{array}{l}\text { This study is the basis for } \\
\text { further studies to be carried } \\
\text { out to unify the process of } \\
\text { seeing work accidents in the } \\
\text { port area. }\end{array}$ \\
\hline $\begin{array}{l}\text { K. Cullinane and D. } \\
\text { W. Song (2006) }\end{array}$ & $\begin{array}{l}\text { Container } \\
\text { terminals in } \\
\text { South Korea: } \\
\text { problems and } \\
\text { panaceas }\end{array}$ & $\begin{array}{l}\text { Data Envelopment } \\
\text { Analysis or Frontier } \\
\text { Production models. }\end{array}$ & $\begin{array}{l}\text { This article examines the } \\
\text { extent of the congestion in } \\
\text { Korean ports, particularly } \\
\text { Pusan, the country's } \\
\text { largest port; and new port } \\
\text { development programs } \\
\text { aimed at attracting private } \\
\text { and foreign funding. }\end{array}$ & $\begin{array}{l}\text { From this analysis, a strategy } \\
\text { for port development in } \\
\text { developing countries can be } \\
\text { drawn. }\end{array}$ \\
\hline L. Potgieter (2016) & $\begin{array}{l}\text { Risk profile } \\
\text { of port } \\
\text { congestion: } \\
\text { cape town } \\
\text { container } \\
\text { terminal case } \\
\text { study }\end{array}$ & $\begin{array}{l}\text { The bow tie method, } \\
\text { which is the most } \\
\text { common method, is } \\
\text { used for this study. }\end{array}$ & $\begin{array}{l}\text { In this study, the timing } \\
\text { effect and frequency of the } \\
\text { sea side and land side port } \\
\text { congestion experienced at } \\
\text { the Cape Town Container } \\
\text { Terminal to develop the } \\
\text { basic risk profiles of } \\
\text { current and future port } \\
\text { congestion. }\end{array}$ & $\begin{array}{l}\text { Port tailbacks outside the } \\
\text { landside congestion and in } \\
2015 \text { proposed to include } \\
\text { the effect of further research } \\
\text { should be done about truck } \\
\text { ban. }\end{array}$ \\
\hline $\begin{array}{l}\text { L. Fan, W. W. } \\
\text { Wilson, and B. Dahl } \\
\text { (2012) }\end{array}$ & $\begin{array}{l}\text { Congestion, } \\
\text { port } \\
\text { expansion } \\
\text { and spatial } \\
\text { competition } \\
\text { for US } \\
\text { container } \\
\text { imports }\end{array}$ & $\begin{array}{l}\text { An intermodal } \\
\text { network flow model } \\
\text { was developed and } \\
\text { used to analyze } \\
\text { congestion in the } \\
\text { logistics system for } \\
\text { container import. }\end{array}$ & $\begin{array}{l}\text { The purpose of this article, } \\
\text { spatial competition of } \\
\text { container imports to the } \\
\text { United States, is to analyze } \\
\text { the congestion and flow. }\end{array}$ & $\begin{array}{l}\text { The findings and results } \\
\text { of this study led to } \\
\text { recommendations for } \\
\text { further research and } \\
\text { recommendations for the Port } \\
\text { of Cape Town, the shipping } \\
\text { industry as a whole. }\end{array}$ \\
\hline
\end{tabular}


The purpose of the AHP is aimed to assign weights to tested factors with assessment of experts. Through this method, weights are assigned to factors to serve two important purposes. First, the factors are prioritized or ranked by way of AHP, hence the key factors are identified. It helps to develop key measures oriented the goal, especially in terms of commercial enterprises. Second, by focusing on key measures, the business decision is given more accurate, the key information for commercial operations is determined more correct, or the alternative marketing strategies are evaluated more accurate [33].

The steps of AHP that is used for this paper are shown in the flow diagram as in Figure 2 [34].

\subsection{AHP Method for Port Congestion}

In this study, the AHP method is used for determining key elements that affect the port congestion, for taking the precaution toward this problem, and for developing new strategies in the matter of port congestion for port investment. In order to identify the most important factors for port congestion, the AHP is most appropriate method. Since, it can assign the weights to the factors that cause port congestion via pairwise comparison between them by the experts. The function of AHP is practical for these goals.

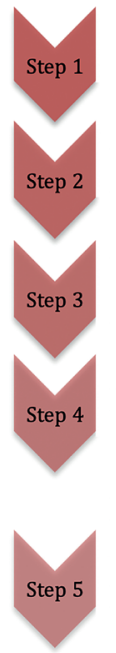

Define problem.

Problem includes a MCDM problem or assesment of importance weigths for tested factors.

Develop hierarchical framework with a goal at the top level, the criteria at the second level, if available the subcriteria at the third level, and if available the alternatives at the final level.

Construct pairwise comparison matrix between all criteria and subcriteria (size $n \times n$ ). The pairwise comparisons generate a matrix of relative rankings for each level of the hierarchy.

The number of matrices depends on the number of elements at each level.

Perform judgement for each pairwise comparisons using scale of relative importance as in Table 2 by experts.

The diagonal values of pairwise comparision must equal to 1 .

Obtain normalized pairwise comparision matrix

or sub criteria

By obtaining normalized values, prioritization of vectors is achieved.

By this way, weights are assigned to the criteria at the end.

For calculating the weights of criteria, the following equation is used:

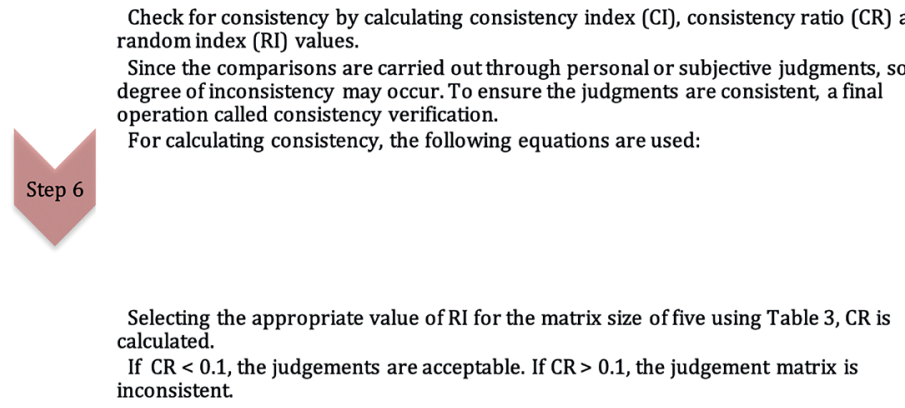

Figure 2. Flow Diagram for AHP 
Table 2. Saaty's Scale for Pairwise Comparisons [31]

\begin{tabular}{|c|c|c|}
\hline $\begin{array}{l}\text { Relative } \\
\text { Intensity }\end{array}$ & Definition & Explanation \\
\hline 1 & Equal value & $\begin{array}{l}\text { Two } \\
\text { requirements are } \\
\text { of equal value }\end{array}$ \\
\hline 3 & $\begin{array}{l}\text { Slightly more } \\
\text { value }\end{array}$ & $\begin{array}{l}\text { Experience } \\
\text { slightly favors one } \\
\text { requirement over } \\
\text { another }\end{array}$ \\
\hline 5 & $\begin{array}{l}\text { Essential or } \\
\text { strong value }\end{array}$ & $\begin{array}{l}\text { Experience } \\
\text { strongly favors } \\
\text { one requirement } \\
\text { over another }\end{array}$ \\
\hline 7 & Very strong value & $\begin{array}{l}\text { A requirement is } \\
\text { strongly favored } \\
\text { and its dominance } \\
\text { is demonstrated } \\
\text { in practice }\end{array}$ \\
\hline 9 & Extreme value & $\begin{array}{l}\text { The evidence } \\
\text { favoring one } \\
\text { over another is } \\
\text { of the highest } \\
\text { possible order of } \\
\text { affirmation }\end{array}$ \\
\hline $2,4,6,8$ & $\begin{array}{l}\text { Intermediate } \\
\text { values between } \\
\text { two adjacent } \\
\text { judgments }\end{array}$ & $\begin{array}{l}\text { When } \\
\text { compromise is } \\
\text { needed }\end{array}$ \\
\hline $\begin{array}{l}1 / 3,1 / 5 \\
1 / 7,1 / 9\end{array}$ & Reciprocals & $\begin{array}{l}\text { Reciprocals } \\
\text { for inverse } \\
\text { comparison }\end{array}$ \\
\hline
\end{tabular}

\subsubsection{Data Collection}

According to AHP, for making pairwise comparison, first, experts should be identified clearly. In this study, ten experts including port state control surveyors, flag state control surveyors and independent surveyors are consulted in order to obtain a scoring the criteria according to the scale of AHP. The inspection of foreign ships in national ports is carried out by port state control surveyors. They verify the condition of the ship, its equipment and manned and operated the ship appropriately according to the requirements of international regulations [35]. The flag state control surveyors inspect the vessels registered under its flag, due to their responsibility and authority on the topic of issuance of safety and pollution prevention document and certification. The independent surveyors take part in almost every stage of cargo operation of ship in port such as draft survey, on-off hire condition survey, preloading-discharging survey, super cargo, tally survey, bunker survey and have to be in ports throughout the entire process. All experts have several experiences to carry out various inspections in accordance with national and international conventions and rules for ships approaching ports. For this reason, port state control, flag state control surveyors, and independent surveyors are the most suitable experts to consult to get the most accurate data to identify the most important factors affecting port congestion.

Secondly, an AHP survey is prepared for determining the most important factors on port congestion. The survey for port congestion includes pairwise comparison between criteria and sub-criteria stated in Table 4.

Table 3. Random Index for AHP

\begin{tabular}{|c|c|c|c|c|c|c|c|c|c|c|c|c|}
\hline $\begin{array}{c}\text { Size of } \\
\text { matrix } \\
\text { (n) }\end{array}$ & 1 & 2 & 3 & 4 & 5 & 6 & 7 & 8 & 9 & 10 & 11 & 12 \\
\hline RI & 0 & 0 & 0.58 & 0.9 & 1.12 & 1.24 & 1.32 & 1.41 & 1.45 & 1.49 & 1.51 & 1.58 \\
\hline
\end{tabular}


Table 4. Criteria and Sub Criteria for Port Congestion

\begin{tabular}{|c|c|c|}
\hline Criteria & Number & Sub criteria \\
\hline \multirow{4}{*}{$\begin{array}{l}\text { Documentation } \\
\text { Procedures }\end{array}$} & D1 & Lack of information and communication technologies \\
\hline & D2 & Customs and port operations \\
\hline & D3 & Lack of influence of owner or charterer \\
\hline & D4 & Deficiencies in the supply program \\
\hline \multirow{5}{*}{ Ship Traffic Inputs } & G1 & Waiting for other ships with ship dock occupation \\
\hline & G2 & The delays in multimodal transportation \\
\hline & G3 & Regional intensity \\
\hline & G4 & Accidents \\
\hline & G5 & Delays in arrival-departure \\
\hline \multirow{5}{*}{ Port Structure } & L1 & Inadequate load capacity of the port \\
\hline & $\mathrm{L} 2$ & Inadequate number of docks at the port \\
\hline & L3 & Inadequate capacity and type of cargo handling equipment \\
\hline & L4 & Insufficient dry-dock capacity \\
\hline & L5 & Insufficient dock depths and tidal effect \\
\hline \multirow{5}{*}{$\begin{array}{l}\text { Port Operation and } \\
\text { Management }\end{array}$} & Y1 & Weakness in the port administration \\
\hline & $\mathrm{Y} 2$ & Inadequate port personnel/ not qualified \\
\hline & Y3 & Inadequate number of port staff and subcontractor workers \\
\hline & Y4 & Low port dependency-cooperation index \\
\hline & Y5 & Inefficient working time of the port and poor operating speed \\
\hline \multirow{6}{*}{$\begin{array}{c}\text { Strategy and } \\
\text { Government Policies }\end{array}$} & S1 & Inadequate public-private collaboration and planning \\
\hline & S2 & War-embargo situations \\
\hline & S3 & Inadequate immigration police procedure and security policy \\
\hline & S4 & Strike-lockout status \\
\hline & S5 & Inadequate fight against pandemic \\
\hline & S6 & $\begin{array}{l}\text { Inadequate port modernization and not construction of new } \\
\text { ports }\end{array}$ \\
\hline
\end{tabular}

\subsubsection{Application of AHP}

\section{Step 1 - Defining the problem}

The research question or the problem is determining which are the most significant factors for port congestion. As mentioned in the literature and introduction section, some studies indicated the factors that cause port congestion, but there is no study that reveals the order of importance among these factors. For this reason, this study aimed determining key elements that affect the port congestion, taking the precaution toward this problem, and developing new strategies in the matter of port congestion for port investment.

\section{Step 2 - Hierarchical structure}

The hierarchical structure in Figure 3 is established to determine what the most important factors for port congestion are. The criteria and sub-criteria in Figure 3 is obtained from previous studies on port congestion mentioned in the introduction 
and literature sections.

\section{Step 3 - Pairwise comparison matrix}

By comparing the sub-criteria belonging to the same group and main criteria, data is obtained from the experts as in Table 5 and aggregated with arithmetic mean to see the common idea.

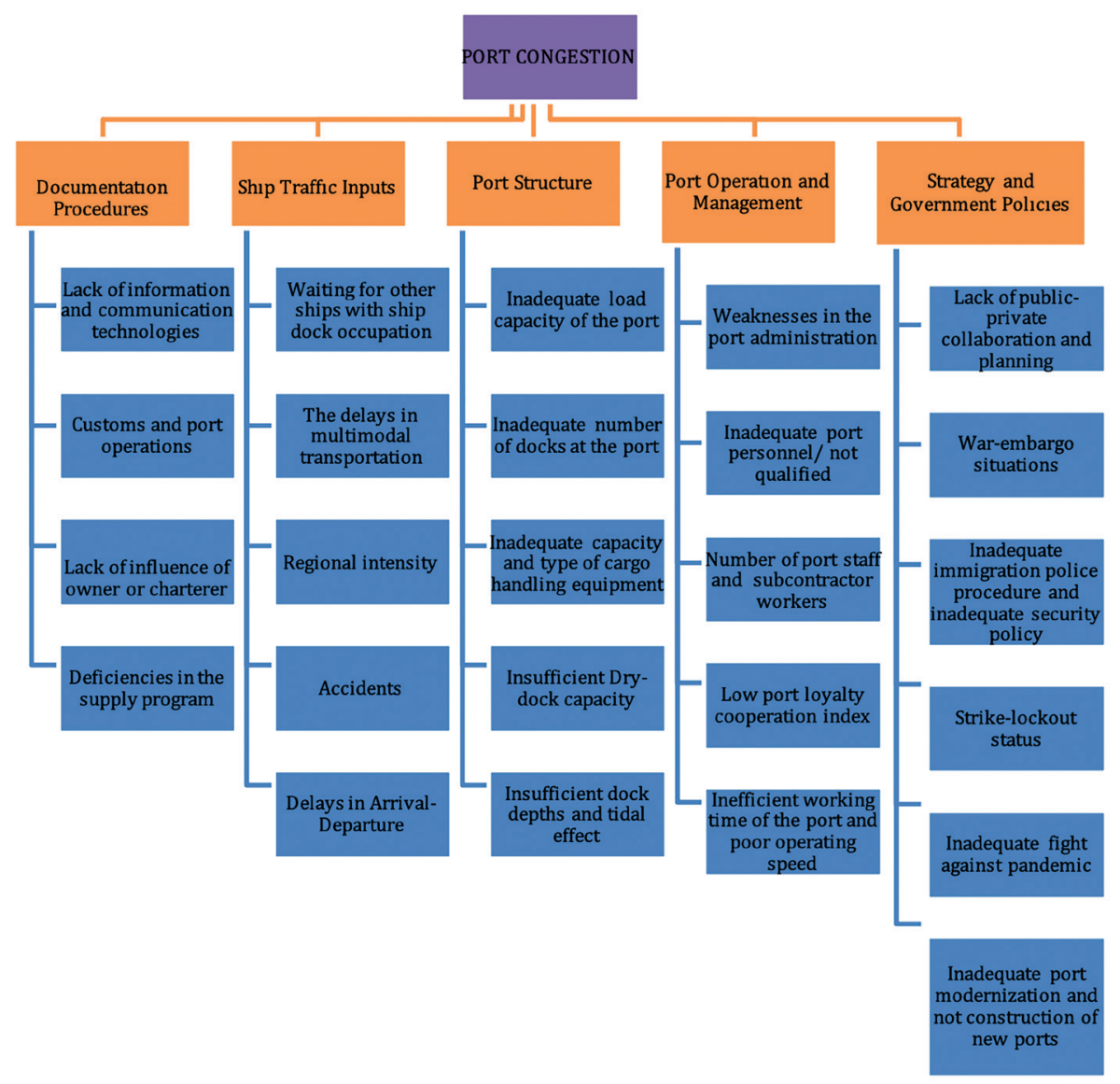

Figure 3. Hierarchical Structure for Port Congestion

Table 5. Pairwise Comparison Matrix and Data from Experts

\begin{tabular}{|c|c|c|c|c|c|c|c|c|c|c|c|c|}
\hline Criteria & $\begin{array}{l}\text { Compared } \\
\text { Factors }\end{array}$ & EXP 1 & EXP 2 & EXP 3 & EXP 4 & EXP 5 & EXP 6 & EXP 7 & EXP 8 & $\begin{array}{c}\text { EXP } \\
9\end{array}$ & EXP 10 & Average \\
\hline \multirow{6}{*}{$\begin{array}{l}\text { documentation } \\
\text { procedures } \\
\text { (D matrix) }\end{array}$} & D1/D2 & 0,25 & 0,14 & 5,00 & 0,50 & 0,13 & 0,20 & 0,20 & 0,17 & 0,14 & 0,33 & 0,71 \\
\hline & D1/D3 & 1,00 & 0,20 & 0,50 & 3,00 & 0,33 & 0,17 & 0,25 & 2,00 & 0,14 & 5,00 & 1,26 \\
\hline & D1/D4 & 5,00 & 0,33 & 4,00 & 3,00 & 0,20 & 0,50 & 0,33 & 0,33 & 2,00 & 3,00 & 1,87 \\
\hline & D2/D3 & 0,20 & 7,00 & 3,00 & 4,00 & 0,33 & 2,00 & 5,00 & 4,00 & 0,20 & 4,00 & 2,97 \\
\hline & $\mathrm{D} 2 / \mathrm{D} 4$ & 6,00 & 5,00 & 0,50 & 0,25 & 0,20 & 2,00 & 6,00 & 0,50 & 1,00 & 6,00 & 2,75 \\
\hline & D3/D4 & 6,00 & 5,00 & 4,00 & 0,25 & 3,00 & 5,00 & 3,00 & 0,25 & 0,17 & 0,20 & 2,69 \\
\hline
\end{tabular}


Table 5. Pairwise Comparison Matrix and Data from Experts (Cont')

\begin{tabular}{|c|c|c|c|c|c|c|c|c|c|c|c|c|}
\hline Criteria & $\begin{array}{l}\text { Compared } \\
\text { Factors }\end{array}$ & EXP 1 & EXP 2 & EXP 3 & EXP 4 & EXP 5 & EXP 6 & EXP 7 & EXP 8 & EXP 9 & EXP 10 & Average \\
\hline \multirow{10}{*}{$\begin{array}{l}\text { ship traffic } \\
\text { inputs } \\
\text { (G matrix) }\end{array}$} & $\mathrm{G} 1 / \mathrm{G} 2$ & 0,20 & 5,00 & 3,00 & 0,33 & 0,13 & 1,00 & 0,17 & 4,00 & 0,25 & 3,00 & 1,71 \\
\hline & $\mathrm{G} 1 / \mathrm{G} 3$ & 3,00 & 3,00 & 2,00 & 0,20 & 0,14 & 0,20 & 0,17 & 0,20 & 5,00 & 1,00 & 1,49 \\
\hline & $\mathrm{G} 1 / \mathrm{G} 4$ & 1,00 & 0,33 & 1,00 & 1,00 & 0,50 & 4,00 & 2,00 & 0,25 & 1,00 & 8,00 & 1,91 \\
\hline & G1/G5 & 0,33 & 0,33 & 2,00 & 0,33 & 0,50 & 4,00 & 0,50 & 0,33 & 8,00 & 1,00 & 1,73 \\
\hline & $\mathrm{G} 2 / \mathrm{G} 3$ & 0,33 & 0,20 & 2,00 & 0,33 & 0,14 & 0,14 & 0,33 & 3,00 & 6,00 & 1,00 & 1,35 \\
\hline & $\mathrm{G} 2 / \mathrm{G} 4$ & 1,00 & 0,20 & 0,33 & 0,33 & 0,50 & 0,50 & 0,25 & 3,00 & 1,00 & 8,00 & 1,51 \\
\hline & G2/G5 & 6,00 & 0,33 & 0,33 & 0,25 & 0,50 & 0,33 & 0,25 & 0,33 & 7,00 & 0,25 & 1,56 \\
\hline & G3/G4 & 1,00 & 0,20 & 0,50 & 1,00 & 7,00 & 6,00 & 5,00 & 3,00 & 6,00 & 8,00 & 3,77 \\
\hline & G3/G5 & 0,50 & 0,20 & 3,00 & 1,00 & 7,00 & 6,00 & 6,00 & 3,00 & 5,00 & 1,00 & 3,27 \\
\hline & G4/G5 & 0,50 & 5,00 & 5,00 & 3,00 & 2,00 & 2,00 & 3,00 & 0,33 & 7,00 & 0,13 & 2,80 \\
\hline \multirow{10}{*}{$\begin{array}{c}\text { port } \\
\text { structure } \\
\text { (L matrix) }\end{array}$} & L1/L2 & 0,25 & 0,33 & 4,00 & 1,00 & 0,13 & 1,00 & 3,00 & 0,33 & 1,00 & 0,50 & 1,15 \\
\hline & L1/L3 & 6,00 & 1,00 & 0,20 & 0,50 & 0,13 & 5,00 & 3,00 & $=1 / 4$ & 1,00 & 2,00 & 2,09 \\
\hline & L1/L4 & 1,00 & 9,00 & 3,00 & 2,00 & 0,13 & 1,00 & 0,33 & 2,00 & 8,00 & 1,00 & 2,75 \\
\hline & L1/L5 & 5,00 & 0,20 & 2,00 & 0,33 & 0,13 & 7,00 & 4,00 & 3,00 & 7,00 & 5,00 & 3,37 \\
\hline & L2/L3 & 5,00 & 3,00 & 0,33 & 1,00 & 0,25 & 0,33 & 4 & 0,33 & 6,00 & 3,00 & 2,14 \\
\hline & L2/L4 & 2,00 & 9,00 & 2,00 & 2,00 & 0,33 & 4,00 & $=1 / 4$ & 3,00 & 7,00 & 3,00 & 3,59 \\
\hline & L2/L5 & 7,00 & 1,00 & 0,17 & 0,33 & 1,00 & 4,00 & 5,00 & 0,50 & 7,00 & 5,00 & 3,10 \\
\hline & L3/L4 & 0,25 & 9,00 & 4,00 & 1,00 & 4,00 & 3 & 0,25 & 3,00 & 7,00 & 4,00 & 3,61 \\
\hline & L3/L5 & 1,00 & 0,33 & 0,20 & 0,50 & 4,00 & 6,00 & 5,00 & 2,00 & 6,00 & 5,00 & 3,00 \\
\hline & L4/L5 & 4,00 & 0,11 & 3,00 & 0,50 & 3,00 & 2,00 & 5,00 & 1,00 & 8,00 & 1,00 & 2,76 \\
\hline \multirow{10}{*}{$\begin{array}{c}\text { port } \\
\text { operation } \\
\text { and } \\
\text { management } \\
\text { (Y matrix) }\end{array}$} & $\mathrm{Y} 1 / \mathrm{Y} 2$ & 1,00 & 0,14 & 0,25 & 2,00 & 5,00 & 0,13 & 0,33 & 0,33 & 6,00 & 2,00 & 1,72 \\
\hline & $\mathrm{Y} 1 / \mathrm{Y} 3$ & 2,00 & 0,14 & 3,00 & 2,00 & 0,11 & 0,17 & 4 & 0,20 & 7,00 & 3,00 & 1,96 \\
\hline & $\mathrm{Y} 1 / \mathrm{Y} 4$ & 0,50 & 0,14 & 0,33 & 1,00 & 3,00 & 1,00 & 4 & 3,00 & 5,00 & 3,00 & 1,89 \\
\hline & Y1/Y5 & 0,25 & 0,14 & 0,50 & 0,33 & 0,14 & 0,25 & 5,00 & 3 & 6,00 & 2,00 & 1,62 \\
\hline & $\mathrm{Y} 2 / \mathrm{Y} 3$ & 2,00 & 1,00 & 0,33 & 1,00 & 2,00 & 4,00 & 0,20 & 3,00 & 0,20 & 1,00 & 1,47 \\
\hline & $\mathrm{Y} 2 / \mathrm{Y} 4$ & 3,00 & 1,00 & 0,25 & 1,00 & 2,00 & 4,00 & 0,20 & 3,00 & 0,20 & 3,00 & 1,77 \\
\hline & Y2/Y5 & 0,50 & 1,00 & 0,25 & 0,33 & 2,00 & 6,00 & 0,20 & 0,33 & 0,17 & 3,00 & 1,38 \\
\hline & Y3/Y4 & 0,33 & 1,00 & 0,20 & 3,00 & 0,33 & 1 & 0,25 & 3,00 & 5,00 & 4,00 & 1,90 \\
\hline & Y3/Y5 & 0,25 & 1,00 & 0,17 & 1,00 & 0,14 & 0,50 & 3,00 & 0,33 & 6,00 & 3,00 & 1,54 \\
\hline & Y4/Y5 & 0,20 & 1,00 & 0,25 & 1,00 & 3,00 & 0,50 & 3,00 & 2,00 & 0,13 & 1,00 & 1,21 \\
\hline
\end{tabular}


Table 5. Pairwise Comparison Matrix and Data from Experts (Cont')

\begin{tabular}{|c|c|c|c|c|c|c|c|c|c|c|c|c|}
\hline Criteria & $\begin{array}{c}\text { Compared } \\
\text { Factors }\end{array}$ & EXP 1 & EXP 2 & EXP 3 & EXP 4 & EXP 5 & EXP 6 & EXP 7 & EXP 8 & EXP 9 & EXP 10 & Average \\
\hline \multirow{15}{*}{$\begin{array}{l}\text { strategy and } \\
\text { government } \\
\text { policies } \\
\text { (S matrix) }\end{array}$} & $\mathrm{S} 1 / \mathrm{S} 2$ & 2,00 & 0,11 & 0,50 & 2,00 & 1,00 & 0,11 & 5,00 & 4,00 & 0,14 & 1,00 & 1,59 \\
\hline & $\mathrm{S} 1 / \mathrm{S} 3$ & 4,00 & 0,14 & 0,25 & 2,00 & 0,33 & 0,33 & 6,00 & 4,00 & 0,17 & 4,00 & 2,12 \\
\hline & $\mathrm{S} 1 / \mathrm{S} 4$ & 9,00 & 0,14 & 0,33 & 1,00 & 1,00 & 0,33 & 5,00 & 4,00 & 0,14 & 4,00 & 2,50 \\
\hline & $\mathrm{S} 1 / \mathrm{S} 5$ & 5,00 & 0,14 & 0,33 & 1,00 & 1,00 & 0,33 & 6,00 & 3,00 & 0,17 & 8,00 & 2,50 \\
\hline & $\mathrm{S} 1 / \mathrm{S} 6$ & 0,33 & 0,14 & 0,50 & 1,00 & 0,17 & 0,25 & 5,00 & 4,00 & 0,14 & 1,00 & 1,25 \\
\hline & $\mathrm{S} 2 / \mathrm{S} 3$ & 0,20 & 9,00 & 0,33 & 2,00 & 0,33 & 9,00 & 0,50 & 1,00 & 5,00 & 0,50 & 2,79 \\
\hline & $\mathrm{S} 2 / \mathrm{S} 4$ & 1,00 & 9,00 & 0,17 & 2,00 & 1,00 & 9,00 & 1,00 & 1,00 & 6,00 & 0,50 & 3,07 \\
\hline & S2/S5 & 0,50 & 9,00 & 0,33 & 2,00 & 1,00 & 9,00 & 0,25 & 0,25 & 6,00 & 0,33 & 2,87 \\
\hline & $\mathrm{S} 2 / \mathrm{S} 6$ & 0,20 & 9,00 & 3,00 & 2,00 & 1,00 & 9,00 & 0,25 & 0,33 & 6,00 & 0,20 & 3,10 \\
\hline & S3/S4 & 1,00 & 0,20 & 0,25 & 0,50 & 3,00 & 1,00 & 2,00 & 1,00 & 5,00 & 4,00 & 1,80 \\
\hline & S3/S5 & 0,50 & 0,20 & 1,00 & 0,50 & 3,00 & 1,00 & 1,00 & 1,00 & 0,20 & 4,00 & 1,24 \\
\hline & S3/S6 & 0,17 & 0,20 & 2,00 & 0,50 & 3,00 & 0,25 & 0,33 & 1,00 & 0,17 & 1,00 & 0,86 \\
\hline & S4/S5 & 1,00 & 5,00 & 0,20 & 2,00 & 1,00 & 1,00 & 0,20 & 0,33 & 5,00 & 0,33 & 1,61 \\
\hline & S4/S6 & 0,17 & 5,00 & 0,33 & 2,00 & 1,00 & 0,25 & 0,25 & 1,00 & 0,20 & 0,17 & 1,04 \\
\hline & S5/S6 & 0,50 & 0,14 & 0,25 & 1,00 & 1,00 & 0,25 & 0,25 & 3,00 & 5,00 & 0,17 & 1,16 \\
\hline \multirow{10}{*}{$\begin{array}{l}\text { main factors } \\
\text { (A matrix) }\end{array}$} & $\mathrm{A} 1 / \mathrm{A} 2$ & 1,00 & 0,33 & 0,20 & 0,50 & 3,00 & 2,00 & 6,00 & 4,00 & 0,17 & 5,00 & 2,22 \\
\hline & $\mathrm{A} 1 / \mathrm{A} 3$ & 5,00 & 0,33 & 0,17 & 1,00 & 0,25 & 3,00 & 5 & 5,00 & 0,14 & 3,00 & 1,99 \\
\hline & $\mathrm{A} 1 / \mathrm{A} 4$ & 4,00 & 0,33 & 0,25 & 0,50 & 0,17 & 0,25 & 7,00 & 5,00 & 0,14 & 1,00 & 1,86 \\
\hline & A1/A5 & 4,00 & 0,33 & 0,50 & 0,50 & 3,00 & 1,00 & 0,14 & 5,00 & 0,17 & 1,00 & 1,56 \\
\hline & $\mathrm{A} 2 / \mathrm{A} 3$ & 2,00 & 0,14 & 2,00 & 0,50 & 5,00 & 0,50 & 5,00 & 0,25 & 0,14 & 0,33 & 1,59 \\
\hline & $\mathrm{A} 2 / \mathrm{A} 4$ & 5,00 & 0,14 & 0,25 & 0,50 & 5,00 & 0,14 & 0,20 & 0,25 & 0,14 & 0,25 & 1,19 \\
\hline & A2/A5 & 5,00 & 0,14 & 0,14 & 2,00 & 0,25 & 0,50 & 0,14 & 0,33 & 0,13 & 0,25 & 0,89 \\
\hline & $\mathrm{A} 3 / \mathrm{A} 4$ & 1,00 & 0,20 & 1,00 & 0,50 & 0,17 & 0,33 & 0,17 & 4,00 & 0,17 & 1,00 & 0,85 \\
\hline & $\mathrm{A} 3 / \mathrm{A} 5$ & 3,00 & 3,00 & 0,33 & 2,00 & 4,00 & 5,00 & 0,17 & 0,33 & 0,13 & 0,50 & 1,85 \\
\hline & A4/A5 & 3,00 & 5,00 & 2,00 & 2,00 & 6,00 & 6,00 & 0,14 & 3,00 & 0,17 & 1,00 & 2,83 \\
\hline
\end{tabular}

\section{Step 4 - Performing judgment of pairwise comparison}

Pairwise comparisons of entire subcriteria are as in Table 6 , and the values in the same column are summed up to prepare for the normalization process in step 5 and indicated on the bottom line.

\section{Step 5 - Weights of criteria}

To obtain weights of criteria, firstly, all values in pairwise comparison matrix belonging to sub criteria and main criteria are normalized. For normalizing the values, each value in the same column is divided by the sum of the values in that column as shown in Step 5 in the flow diagram. Then, Criteria weights 
(wi) of the sub criteria and main criteria are found according to equation in Step 6 in the obtained by using equation in Step 5 in the flow diagram. The results of all these steps flow diagram. Finally, to make consistency for each criteria and sub criteria are given analysis in Step 6, Di and Ei values are in the Table 7.

Table 6. Pairwise Comparisons of Entire Sub-Criteria and Main Criteria

\begin{tabular}{|c|c|c|c|c|}
\hline D matrix & D1 & D2 & D3 & D4 \\
\hline D1 & 1,00 & 0,71 & 1,26 & 1,87 \\
\hline D2 & 1,41 & 1,00 & 2,97 & 2,75 \\
\hline D3 & 0,79 & 0,34 & 1,00 & 2,69 \\
\hline D4 & 0,53 & 0,36 & 0,37 & 1,00 \\
\hline SUM & 3,736860856 & 2,410337 & 5,6017472 & 8,31 \\
\hline
\end{tabular}

\begin{tabular}{|c|c|c|c|c|c|}
\hline G matrix & G1 & G2 & G3 & G4 & G5 \\
\hline G1 & 1,00 & 1,71 & 1,49 & 1,91 & 1,73 \\
\hline G2 & 0,58 & 1,00 & 1,35 & 1,51 & 1,56 \\
\hline G3 & 0,67 & 0,74 & 1,00 & 3,77 & 3,27 \\
\hline G4 & 0,52 & 0,66 & 0,27 & 1,00 & 2,80 \\
\hline G5 & 0,58 & 0,64 & 0,31 & 0,36 & 1,00 \\
\hline SUM & 3,357531153 & 4,754018 & 4,4110624 & 8,547143 & 10,36 \\
\hline L matrix & L1 & L2 & L3 & L4 & L5 \\
\hline L1 & 1,00 & 1,15 & 2,09 & 2,75 & 3,37 \\
\hline L2 & 0,87 & 1,00 & 2,14 & 3,59 & 3,10 \\
\hline L3 & 0,48 & 0,47 & 1,00 & 3,61 & 3,00 \\
\hline L4 & 0,36 & 0,28 & 0,28 & 1,00 & 2,76 \\
\hline L5 & 0,30 & 0,32 & 0,33 & 0,36 & 1,00 \\
\hline SUM & 3,008406386 & 3,218422 & 5,8403416 & 11,31232 & 13,23 \\
\hline Y matrix & Y1 & Y2 & Y3 & Y4 & Y5 \\
\hline Y1 & 1,00 & 1,72 & 1,96 & 1,89 & 1,62 \\
\hline Y2 & 0,58 & 1,00 & 1,47 & 1,77 & 1,38 \\
\hline Y3 & 0,51 & 0,68 & 1,00 & 1,90 & 1,54 \\
\hline Y4 & 0,53 & 0,56 & 0,53 & 1,00 & 1,21 \\
\hline Y5 & 0,62 & 0,72 & 0,65 & 0,83 & 1,00 \\
\hline SUM & 3,23798391 & 4,689882 & 5,6056664 & 7,386446 & 6,75 \\
\hline
\end{tabular}

\begin{tabular}{|c|c|c|c|c|c|c|}
\hline S matrix & S1 & S2 & S3 & S4 & S5 & S6 \\
\hline S1 & 1,00 & 1,59 & 2,12 & 2,50 & 2,50 & 1,25 \\
\hline S2 & 0,63 & 1,00 & 2,79 & 3,07 & 2,87 & 3,10 \\
\hline S3 & 0,47 & 0,36 & 1,00 & 1,80 & 1,24 & 0,86 \\
\hline
\end{tabular}


Table 6. Pairwise Comparisons of Entire Sub-Criteria and Main Criteria (Cont')

\begin{tabular}{|c|c|c|c|c|c|c|}
\hline S matrix & S1 & S2 & S3 & S4 & S5 & S6 \\
\hline S4 & 0,40 & 0,33 & 0,56 & 1,00 & 1,61 & 1,04 \\
\hline S5 & 0,40 & 0,35 & 0,81 & 0,62 & 1,00 & 1,16 \\
\hline S6 & 0,80 & 0,32 & 1,16 & 0,96 & 0,86 & 1,00 \\
\hline SUM & 3,70 & 3,945169 & 8,4347979 & 9,952656 & 10,08207 & 8,41 \\
\hline A matrix & A1 & \multicolumn{2}{|c|}{ A2 } & A3 & A4 & A5 \\
\hline A1 & 1,00 & 2,22 & 1,99 & 1,86 & 1,56 \\
\hline A2 & 0,45 & 1,00 & 1,59 & 1,19 & 0,89 \\
\hline A3 & 0,50 & 0,63 & 1,00 & 0,85 & 1,85 \\
\hline A4 & 0,54 & 0,84 & 1,18 & 1,00 & 2,83 \\
\hline A5 & 0,64 & 1,12 & 0,54 & 0,35 & 1,00 \\
\hline SUM & 3,13 & 5,81 & 6,30 & 5,25 & 8,13 \\
\hline
\end{tabular}

Table 7. Normalized Pairwise Comparisons and Criteria Weights of the Entire Sub-Criteria and Main Criteria

\begin{tabular}{|c|c|c|c|c|c|c|c|}
\hline D matrix & D1 & D2 & D3 & D4 & $\begin{array}{c}\text { Criteria } \\
\text { Weights } \\
\text { (wi) }\end{array}$ & Di்= $\mathbf{i w i * a i j}$ & Ei=wi/Di \\
\hline D1 & 0,27 & 0,29 & 0,22 & 0,23 & 0,25 & 1,04 & 4,11 \\
\hline D2 & 0,38 & 0,41 & 0,53 & 0,33 & 0,41 & 1,73 & 4,20 \\
\hline D3 & 0,21 & 0,14 & 0,18 & 0,32 & 0,21 & 0,88 & 4,11 \\
\hline D4 & 0,14 & 0,15 & 0,07 & 0,12 & 0,12 & 0,49 & 4,04 \\
\hline SUM & 1 & 1 & 1 & 1 & & & \\
\hline
\end{tabular}

\begin{tabular}{|c|c|c|c|c|c|c|c|c|}
\hline $\begin{array}{c}\text { G } \\
\text { matrix }\end{array}$ & G1 & G2 & G3 & G4 & G5 & $\begin{array}{c}\text { Criteria } \\
\text { Weights } \\
\text { (wi) }\end{array}$ & Dí= $\mathbf{w i * a i j}$ & $\begin{array}{c}\text { Ei=wi / } \\
\text { Di }\end{array}$ \\
\hline G1 & 0,30 & 0,36 & 0,34 & 0,22 & 0,17 & 0,28 & 1,49 & 5,36 \\
\hline G2 & 0,17 & 0,21 & 0,31 & 0,18 & 0,15 & 0,20 & 1,11 & 5,46 \\
\hline G3 & 0,20 & 0,16 & 0,23 & 0,44 & 0,32 & 0,27 & 1,50 & 5,60 \\
\hline G4 & 0,16 & 0,14 & 0,06 & 0,12 & 0,27 & 0,15 & 0,79 & 5,30 \\
\hline G5 & 0,17 & 0,13 & 0,07 & 0,04 & 0,10 & 0,10 & 0,53 & 5,14 \\
\hline SUM & 1 & 1 & 1 & 1 & 1 & & & \\
\hline
\end{tabular}


Table 7. Normalized Pairwise Comparisons and Criteria Weights of the Entire Sub-Criteria and Main Criteria (Cont')

\begin{tabular}{|c|c|c|c|c|c|c|c|c|c|}
\hline \multicolumn{2}{|c|}{ L matrix } & L1 & 2 & L3 & L4 & L5 & $\begin{array}{l}\text { Criteria } \\
\text { Weights } \\
\text { (wi) }\end{array}$ & $\mathrm{DI}=\sum \mathbf{w i}^{*} \mathbf{a i j}$ & Ei=wi /Dİ \\
\hline \multicolumn{2}{|l|}{ L1 } & ,33 & 36 & 0,36 & 0,24 & 0,25 & 0,31 & 1,63 & 5,29 \\
\hline \multicolumn{2}{|l|}{$\mathrm{L} 2$} & 0,29 & 31 & 0,37 & 0,32 & 0,23 & 0,30 & 1,63 & 5,37 \\
\hline \multicolumn{2}{|l|}{ L3 } & ),16 & 15 & 0,17 & 0,32 & 0,23 & 0,20 & 1,11 & 5,44 \\
\hline \multicolumn{2}{|l|}{ L4 } &, 12 & 09 & 0,05 & 0,09 & 0,21 & 0,11 & 0,56 & 5,12 \\
\hline \multicolumn{2}{|l|}{ L5 } &, 10 & 10 & 0,06 & 0,03 & 0,08 & 0,07 & 0,37 & 5,09 \\
\hline \multicolumn{2}{|l|}{ SUM } & 1 & 1 & 1 & 1 & 1 & & & \\
\hline \multicolumn{2}{|c|}{ Y matrix } & Y1 & 2 & Y3 & Y4 & Y5 & $\begin{array}{c}\text { Criteria } \\
\text { Weights } \\
\text { (wi) }\end{array}$ & Dİ= $\sum w i^{*} a i j$ & Ei=wi /Dİ \\
\hline \multicolumn{2}{|l|}{ Y1 } &, 31 & 37 & 0,35 & 0,26 & 0,24 & 0,30 & 1,56 & 5,12 \\
\hline \multicolumn{2}{|l|}{$\mathrm{Y} 2$} &, 18 & 21 & 0,26 & 0,24 & 0,20 & 0,22 & 1,12 & 5,12 \\
\hline \multicolumn{2}{|l|}{ Y3 } &, 16 & 15 & 0,18 & 0,26 & 0,23 & 0,19 & 0,98 & 5,09 \\
\hline \multicolumn{2}{|l|}{ Y4 } &, 16 & 12 & 0,09 & 0,14 & 0,18 & 0,14 & 0,70 & 5,05 \\
\hline \multicolumn{2}{|l|}{ Y5 } &, 19 & 15 & 0,12 & 0,11 & 0,15 & 0,14 & 0,73 & 5,07 \\
\hline \multicolumn{2}{|l|}{ SUM } & 1 & 1 & 1 & 1 & 1 & & & \\
\hline $\begin{array}{c}\mathrm{S} \\
\text { matrix }\end{array}$ & S1 & S2 & S3 & S4 & S5 & S6 & $\begin{array}{c}\text { Criteria } \\
\text { Weight } \\
\text { (wi) }\end{array}$ & $\mathrm{D} \mathbf{I}=\sum \mathrm{wi}^{*}$ & $\begin{array}{c}\text { Ei=wi / } \\
\text { Dİ }\end{array}$ \\
\hline S1 & 0,27 & 0,40 & 0,25 & 0,25 & 0,25 & 0,15 & 0,26 & 1,65 & 6,28 \\
\hline S2 & 0,17 & 0,25 & 0,33 & 0,31 & 0,28 & 0,37 & 0,29 & 1,79 & 6,25 \\
\hline S3 & 0,13 & 0,09 & 0,12 & 0,18 & 0,12 & 0,10 & 0,12 & 0,77 & 6,22 \\
\hline S4 & 0,11 & 0,08 & 0,07 & 0,10 & 0,16 & 0,12 & 0,11 & 0,66 & 6,18 \\
\hline S5 & 0,11 & 0,09 & 0,10 & 0,06 & 0,10 & 0,14 & 0,10 & 0,61 & 6,20 \\
\hline S6 & 0,22 & 0,08 & 0,14 & 0,10 & 0,09 & 0,12 & 0,12 & 0,76 & 6,16 \\
\hline SUM & 1 & 1 & 1 & 1 & 1 & 1 & & & \\
\hline A matrix & A1 & A2 & A3 & A4 & A5 & Criter & $\begin{array}{l}\text { eria Weights } \\
\text { (wi) }\end{array}$ & $\mathrm{DI}=\sum \mathbf{w i}^{*} \mathbf{a}$ & Ei=wi /Dí \\
\hline $\mathrm{A} 1$ & 0,32 & 0,38 & 0,32 & 0,35 & 0,19 & & 0,31 & 1,64 & 5,24 \\
\hline $\mathrm{A} 2$ & 0,14 & 0,17 & 0,25 & 0,23 & 0,11 & & 0,18 & 0,95 & 5,25 \\
\hline A3 & 0,16 & 0,11 & 0,16 & 0,16 & 0,23 & & 0,16 & 0,86 & 5,27 \\
\hline $\mathrm{A} 4$ & 0,17 & 0,14 & 0,19 & 0,19 & 0,35 & & 0,21 & 1,10 & 5,29 \\
\hline A5 & 0,20 & 0,19 & 0,09 & 0,07 & 0,12 & & 0,13 & 0,70 & 5,19 \\
\hline SUM & 1 & 1 & 1 & 1 & 1 & & & & \\
\hline
\end{tabular}




\section{Step 6 - Consistency verification}

In order to identify the most important factors for port congestion, after the data is received from the experts, it is checked whether these data are consistent or not. For this purpose, in the consistency analysis, the values of max, consistency index (CI), consistency ratio (CR) and random index (RI) are calculated according to equations in step 6 in the flow diagram. The results of the consistency analysis for each matrix are shown in Table 8. According to analysis, if $\mathrm{CR}<0,10$, the result is consistent.

Table 8. Results of Consistency Analysis

\begin{tabular}{|c|c|c|c|c|}
\hline Matrices & $\lambda \max$ & CI & RI & CR \\
\hline D matrix & 4,11 & 0,04 & 0,9 & 0,04 \\
\hline G matrix & 5,37 & 0,09 & 1,12 & 0,08 \\
\hline L matrix & 5,36 & 0,07 & 1,12 & 0,06 \\
\hline Y matrix & 5,09 & 0,02 & 1,12 & 0,02 \\
\hline S matrix & 6,22 & 0,04 & 1,24 & 0,03 \\
\hline A matrix & 5,25 & 0,06 & 1,12 & 0,06 \\
\hline
\end{tabular}

\subsubsection{Findings}

According to consistency analysis, the results of all pair wise comparisons are consistent and from the result of the consistency, it is understood to valid to specify the order of importance of factors for port congestion. Examining the Table 7 , it is seen that the most important main factor for port congestions is documentation procedures (A1). The order of important main factor for port congestion is as port operation and management (A4), ship traffic inputs (A2), port structure (A3) and strategy and government relations (A5), respectively.

In the Table 7 , it is understood that the most important factor among the sub-factors of documentation procedures for port congestion is the procedures in port and customs operations (D2). This is followed by the lack of information and communication technologies (D1), the lack of influence of the ship owner or charterer (D3) and the deficiencies in the supply program (D4).

According to results, the weakness in the port administration (Y1) is the most important factor among the sub-factors of port operation and management for port congestion. Then, the lack of qualified port personnel (Y2) and insufficient number of port personnel (Y3) follow it, while the low port loyalty cooperation index (Y4) and the inefficient working time of the port and inadequate operating speed (Y5) are in the last rank with the same criteria weights.

In addition, the most important factor among the sub-factors of ship traffic inputs for port congestion is the waiting for other ships with ship dock occupation (G1). Regional density (G3), delays in connections in multi-model transportation (G2), accidents (G4) and delays in arrivaldeparture (G5) come after it.

When Table 7 is examined, it is understood that the most important factor among the port structure sub-factors for port congestion is the inadequate load capacity of the port (L1). This is followed by insufficient number of docks (L2) at the port, insufficient capacity and type (L3) of cargo handling equipment, insufficient dry-dock capacity (L4) and insufficient dock depths and tidal effect (L5).

Finally, the most important factors among the sub-factors of strategy and state policy for port congestion are war and embargo situations (S2). This is followed by insufficient public-private cooperation and planning (S1), while insufficient immigration police procedure and insufficient security policy (S3), and insufficient port modernization and new constructions (S6) share third order. The strike-lockout situation (S4) and insufficient outbreak (S5) are in the last two places, respectively. 


\section{Conslusion}

In this study, it is aimed to identify most important factors on congestion of a port according to point of view of the port state control surveyors, flag state surveyors, and independent surveyors. For this purpose, the factors affecting the port congestion obtained from the literature are ordered according to criteria weights using the AHP method.

According to results, it is observed that the main factors for port congestion with the highest importance are documentation procedures, port operation and management, ship traffic inputs, port structure and strategy and government relations, respectively. The most important sub factors are the procedures in port and customs operations, weakness in the port administration, the waiting for other ships with ship dock occupation, inadequate load capacity of the port, and War and embargo situations. When the waiting for other ships with ship dock occupation and inadequate load capacity of the port are considered as one of the important sub factors for port congestion, in this context, by building new hub and sub ports regional density can be reduced, with both port dependency and integrity dock occupation and inadequate capacity of number of docks problems can be solved or as much as possible minimized. Examining the port operation and management in detail, which is one of the important main factor for port congestion, the research findings indicated that the weakness in the port administration is most important sub factor in this category. Taking this factor into account, by investigating the foreign ports' best management practices in terms of operation and management, qualified and sufficiently quantified personnel in port for both management and operational departments can be obtained by a combination of sufficient salary, tax relief and encouragement. In this way, can make an action for the topic of port congestion in the sense of port operation and management. On the other hand, via strategy and governmental relations take place in the end point to affect port congestion, with public-private partnership, a strategic planning can be developed for preventing port congestion efficiently. And finally, new technologies (radio-label-scan) can be integrated to the system to establish digital customization systems (e-manifest, e-bl, etc.) to minimize human factors in the official part of the sector, minimize time spend and to minimize errors, by means of automation.

This paper makes an effort to contribute to the existing literature by determining importance weights of factors leading to port congestion as the unique study on the matter. Therefore, the ports that have port congestion problems may gain an insight into which areas they should develop and a port investor can also refer to these factors when creating a new port project. For further studies, it is considered that grey relational analysis can be practiced for ranking order of some ports taking place in the specific area in accordance with port congestion. For example, five ports can be analyzed in the İstanbul port area or in any other port area and they can be used as alternative for the grey relational analysis. Since, the weighting of the factors effecting port congestion has been obtained from this research, in the further study, real data regarding these factors of the determined ports is obtained. After grey analysis, determined ports are ranked according to the level of port congestion which they have. In this way, the map of port congestion for determined port area may be obtained.

\section{References}

[1] Haralambides, H. E. (2007).Structure and Operations in the Liner Shipping Industry. Handbook o. Emerald Group Publishing Limited. 
[2] Maneno, F. H. (2019). Assessment of Factors Causing Port Congestion: A Case of The Port Dar es Salaam (MSc Thesis). World Maritime University.

[3] Tongozo, J. (1989). The Impacts of Wharf Age Costs on Victoria's ExportOriented Industries.Econ. Ppaer, 8, 58-64.

[4] Nilsson, S. O. (1985). Port Management. In: First Nat. Conf. On Dock And Harbour Engineering (pp 307). City: Bombay, India, Indian Inst. Technol., Theme A, Paper 18.

[5] Nze, I. C. and Onyemechi,C. (2018). Port Congestion Determinants and Impacts on Logistics and Supply Chain Network of Five African Ports. J. Sustain. Dev. Transp. Logist., 3 (1), 70-82. doi: 10.14254/ jsdtl.2018.3-1.7.

[6] Manaadiar,H. (2020). Port Congestion - Causes, Consequences and Impact on Global Trade.Shipping and Freight Resource. Retrieved September 12, 2020, from https:// shippingandfreightresource.com/ port-congestion-causes-and-impacton-global-trade/\#.

[7] Jansson, L. O. and Shneerson,D. (1982).Port Economics. City: The MIT Press, Cambridge, Massachusetts, and London, England.

[8] UNCTAD. (2019).Review of Maritime Transport 2019. City: United Nations, Geneva.https://unctad.org/system/ files/official-document/rmt2019_ en.pdf

[9] Gidado,U. (2015). Consequences of Port Congestion on Logistics and Supply Chain in African Ports.Dev. Ctry. Stud., 5 (6), 160-168.

[10] Bolat, F. and Guler,N. (2015). Hub Port Potential of Marmara Region in Turkey by Network-Based Modelling. Proc. Inst. Civ. Eng. Transp., 168 (2), 172-187.doi: 10.1680/ tran.13.00043.
[11] Lirn,T. C., Thanopoulou,H. A., Beynon,M. J. and Beresford,A. K. C. (2004). An Application of AHP on Transhipment Port Selection: A Global Perspective.Marit. Econ. Logist., 6 (1), 70-91. doi: 10.1057/ palgrave.mel.9100093.

[12] Guan, C. Q. and Liu,R. (2009). Modeling Gate Congestion of Marine Container Terminals, Truck Waiting Cost, and Optimization. Transp. Res. Rec., 2100, 58-67. doi: 10.3141/2100-07.

[13] Nyema,S. M. (2014). Factors Influencing Container Terminals Efficiency: a Case Study of Mombasa Entry Port.Eur. J. Logist. Purch. Supply Chain Manag., 2 (3), 39-78. doi: 2054-0949.

[14] Oyatoye, E. O., Okoye, C. J. and Sulaimon,A. (2011). Application of Queueing Theory to Port Congestion Problem in Nigeria.Eur. J. Bus. Manag., 3 (38), 2222-2839.

[15] Veloqui, M., Turias, I., Cerbán, M. M., González, M. J., Buiza, G. and Beltrán, J. (2014). Simulating the Landside Congestion in a Container Terminal. The Experience of the Port of Naples (Italy).Procedia - Soc. Behav. Sci., 160,M615-624. doi: 10.1016/j. sbspro.2014.12.175.

[16] Dekker,R., Van Der Heide,S., Van Asperen,E. and Ypsilantis,P. (2013). A chassis Exchange Terminal to Reduce Truck Congestion at Container Terminals.Flex. Serv. Manuf. J., 25 (4), 528-542. doi: 10.1007/s10696-012-9146-3.

[17] Jin,J. G., Lee,D. H. and $\mathrm{Hu}, \mathrm{H}$. (2015). Tactical Berth and Yard Template Design at Container Transshipment Terminals: A Column Generation based Approach.Transp. Res. Part E Logist. Transp. Rev., 73, 168-184. doi: $10.1016 /$ j.tre.2014.11.009. 
[18] Ke,G. Y., Li,K. W. and Hipel,K. W. (2012). An Integrated Multiple Criteria Preference Ranking Approach to The Canadian West Coast Port Congestion Conflict.Expert Syst. Appl., 39 (10), 9181-9190. doi: 10.1016/j.eswa.2012.02.086.

[19] Mollaoğlu,M., Bucak,U. and Demirel,H. (2019). A Quantitative Analysis of the Factors That May Cause Occupational Accidents at Ports. J. ETA Marit. Sci., 7 (4), 294-303. doi: 10.5505/ jems.2019.15238.

[20] Cullinane, K. and Song,D. W. (1998). Container Terminals in South Korea: Problems and Panaceas.Marit. Policy Manag., 25 (1), 63-80. doi: $10.1080 / 03088839800000045$.

[21] Potgieter,L. (2016). Risk Profile of Port Congestion: Cape Town Container Terminal Case study (MSc Thesis). Stellenbosch University.

[22] Fan,L., Wilson,W. W. and Dahl,B. (2012).Congestion, Port Expansion and Spatial Competition for US Container Imports.Transp. Res. Part E Logist. Transp. Rev., 48 (6), 1121-1136. doi: 10.1016/j. tre.2012.04.006.

[23] Gül Emecen, E. (2004). Marmara Bölgesi Limanlarinin Çok Kanalli KuyruTeorisiyle Talep Ve İşletme Yönetim Modelin Geliștirilmesi (PhD Thesis). Istanbul University.

[24] Zorlu,Ö. (2008). Analysing of Management Efficiency of Turkish Ports and Necessity of Transit Port (MSc THesis). Istanbul Technical University.

[25] Yeo,G.-T., Roe,M. and Soak,S.-M. (2007). Evaluation of the Marine Traffic Congestion of North Harbor in Busan Port.J. Waterw. Port, Coastal, Ocean Eng., 133 (2), 87-93. doi: 10.1061/(asce)0733950x(2007)133:2(87).
[26] Abualhaol,I., Falcon,R., Abielmona,R. and Petriu,E. (2018). Mining Port Congestion Indicators from Big AIS Data.Proc. Int. Jt. Conf. Neural Networks. IEEE. doi: 10.1109/ IJCNN.2018.8489187.

[27] Saeed,N., Song,D. W. and Andersen,O. (2018). Governance Mode for Port Congestion Mitigation: A Transaction Cost Perspective.NETNOMICS Econ. Res. Electron. Netw., 19 (3), 159178. doi: 10.1007/s11066-0189123-4.

[28] Neagoe,M., Nguyen,H. O., Taskhiri,M. S. and Turner,P. (2017). Port Terminal Congestion Management:An Integrated Information Systems Approach for Improving Supply Chain Value. Proc. 28th Australas. Conf. Inf. Syst. ACIS 2017(pp. 1-9). City: Australia.

[29] Li,B., Tan,K. W. and Tran,K. T. (2016). Traffic Simulation Model for Port Planning and Congestion Prevention. Proc. - Winter Simul. Conf. (pp. 2382-2393).City: WSC 2016: Winter Simulation Conference, Washington, DC. Research Collection School of Information Systems. doi: 10.1109/ WSC.2016.7822278.

[30] Pruyn,J. F. J., Kana,A. A. and Groeneveld,W. M. (2020).Analysis of Port Waiting Time due to Congestion by Applying Markov Chain Analysis.In Editors (Thierry, Vanelslander; Christa, Sys), Maritime Supply Chains (Chapter 4, pp. 69-94). Elsevier Inc.

[31] Saaty,T. L. (1980). The Analytic Hierarchy Process: Planning.Prior. Setting. Resour. Alloc. MacGraw-Hill. City: New York Int. B. Co.

[32] Taherdoost,H. (2018). Decision Making Using the Analytic Hierarchy Process (AHP); A Step by Step Approach.Int. Journel Econ. Manag. Syst., 2, 244-246, 2018. 
[33] Cheng, E. W. l. and Li,H. (2001). Analytic Hierarchy Process: An Approach to Determine Measures for Business Performance.Meas. Bus. Excell., 5 (3), 30-37. doi: 10.1108/ EUM0000000005864.

[34] Velmurugan,R., Selvamuthukumar,S. and Manavalan,R. (2011). Multi Criteria Decision Making to Select The Suitable Method for The Preparation of Nanoparticles using an Analytical Hierarchy Process.Pharmazie, 66 (11), 836-842. doi: 10.1691/ph.2011.1034.

[35] IMO. Port state control.International Maritime Organization. Retrived September 20, 2020, from http:// www.imo.org/en/OurWork/MSAS/ Pages / PortStateControl.aspx. [Accessed: 10-Jun-2020]. 